\title{
INFLUENCE OF WALKING DIRECTION ON THE INTRA-LIMB COORDINATION OF HEALTHY CHILDREN AGED BETWEEN THREE AND SIX
}

\section{INFLUENTA DIRECTIEI DE MERS ASUPRA COORDONĂRII MEMBRELOR INFERIOARE LA COPIII SĂNĂTOŞI CU VÂRSTE ÎNTRE TREI ŞI ŞASE ANI}

\author{
Jinghui ZHANG ${ }^{1,2}$, Jinlong $\mathrm{LIU}^{1,2}$, Bo XU ${ }^{1,2}$, Wuyong $\mathrm{CHEN}^{1,2}$, Jianxin $\mathrm{WU}^{3}$, Jin ZHOU ${ }^{1,2^{*}}$ \\ ${ }^{1}$ National Engineering Laboratory for Clean Technology of Leather Manufacture, Sichuan University, \\ Chengdu 610065, P.R. China \\ ${ }^{2}$ Key Laboratory for Leather Chemistry and Engineering of the Education Ministry, Chengdu 610065, P.R. China \\ ${ }^{3}$ Science Lab, Zhejiang Red Dragonfly Footwear Co., Ltd., Wenzhou 325105, P.R. China
}

INFLUENCE OF WALKING DIRECTION ON THE INTRA-LIMB COORDINATION OF HEALTHY CHILDREN AGED BETWEEN THREE AND SIX

\begin{abstract}
The aim of this study was first to compare the differences of coordination between forward walking (FW) and reversed backward walking (RevBW) in 40 healthy children aged between three and six; and then to explore interaction effects of age and direction of motion on intra-limb coordination. Kinematics of FW and RevBW of those subjects were measured by Coda motion system. Based on the Euler angle (EA) and angle velocity in knee (OAB), ankle (ABD) and metatarsophalangeal joint (MTH)(BDF), continuous relative phase (CRP) between knee-ankle ( $\left.\theta_{C R P}(\mathbf{K}-\mathbf{A})\right)$ and ankle-metatarsophalangeal ( $\left.\theta_{C R P}(\mathbf{A}-\mathbf{M})\right)$ were calculated. Coefficient of variance between FW and RevBW in each EA and CRP variable were figured out. Statistical model of independent T test and paired T test, as well as univariate analysis were applied with significant level of 0.05 and confidence interval of $95 \%$. Our results show that RevBW significantly increased the amplitude of knee, ankle and MTH joint; while majority of inter-age CoV-EA variables were found less prominent, with exception of CoV-EA (OAB) between ages of five to six. Amplitude-EA variables were recorded with significant differences between FW and RevBW in each age group. In terms of interaction effects, only walking direction showed significant impact on the variables of amplitude-EA. Overall, although BW increased amplitude of motion in knee, ankle and MTH joint, children aged between three and six have already achieved a mechanism that central nervous system could switch their gait control freely.
\end{abstract}

KEY WORDS: walking direction, coordination, continuous relative phase, children

INFLUENȚA DIRECȚIEI DE MERS ASUPRA COORDONĂRII MEMBRELOR INFERIOARE LA COPIII SĂNĂTOȘI CU VÂRSTE ÎNTRE TREI ȘI ȘASE ANI

REZUMAT. Scopul acestui studiu a fost în primul rând de a compara diferențele de coordonare dintre mersul înainte (FW) și mersul înapoi inversat (RevBW), la 40 de copii sănătoși, cu vârstele cuprinse între trei și șase ani și apoi de a explora efectele interacțiunii dintre vârstă și direcția de mișcare asupra coordonării membrelor. S-a măsurat cinematica mersului înainte și a mersului înapoi inversat al acestor subiecți utilizând sistemul Coda motion. Pornind de la unghiul lui Euler (EA) și viteza unghiului la articulațiile genunchilor (OAB), gleznelor (ABD) și metatarsienelor (BDF), s-a calculat faza continuă relativă (CRP) între genunchi și gleznă ( $\left.\theta_{C R P}(\mathrm{~K}-\mathrm{A})\right)$ și între gleznă și metatarsiene ( $\theta_{C R P}(\mathrm{~A}-$ M)). S-a determinat coeficientul de variație între mersul înainte și mersul înapoi inversat pentru fiecare variabilă EA și CRP. S-au aplicat modelele statistice ale testului $\mathrm{t}$ independent și testului t cu eșantioane pereche, precum și analiza univariată cu un nivel de semnificație de 0,05 și un interval de încredere de $95 \%$. Rezultatele noastre arată că mersul înapoi inversat a crescut în mod semnificativ amplitudinea articulațiilor genunchiului, gleznei și metatarsienelor, iar majoritatea variabilelor CoV-EA inter-vârstă au fost mai puțin proeminente, cu excepția CoV-EA (OAB), între vârsta de cinci și șase ani. Variabilele amplitudine-EA au prezentat diferente semnificative între mersul înainte și mersul înapoi inversat în fiecare grupă de vârstă. În ceea ce privește efectele interacțiunii, doar direcția de mers a avut un impact semnificativ asupra variabilelor amplitudine-EA. În general, cu toate că mersul înapoi a crescut amplitudinea mișcării în zona articulațiilor genunchiului, gleznei și metatarsienelor, copiii cu vârste cuprinse între trei și șase ani au dezvoltat un mecanism care permite sistemului nervos central să-și controleze mersul în orice direcție.

CUVINTE CHEIE: direcție de mers, coordonare, fază relativă continuă, copii

L'INFLUENCE DE L'ORIENTATION DE MARCHE SUR LA COORDINATION ENTRE LES MEMBRES CHEZ LES ENFANTS SAINS ÂGÉS ENTRE TROIS ET SIX ANS

RÉSUMÉ. Le but de cette étude a été d'abord de comparer les différences de coordination entre la marche avant (FW) et la marche arrière inversée (RevBW) chez 40 enfants en bonne santé âgés de trois à six ans et puis d'explorer les effets de l'interaction entre l'âge et la direction du mouvement sur la coordination intra-membre. La cinématique de la marche avant et de la marche arrière inversée de ces sujets a été mesurée par le système Coda motion. À partir de l'angle d'Euler (EA) et de la vitesse angulaire dans les articulations du genou (OAB), de la cheville ( $A B D)$ et des métatarsophalangiennes (BDF), on a calculé la phase relative continue (CRP) entre le genou et la cheville ( $\left.\theta_{C R P}(\mathrm{~K}-\mathrm{A})\right)$ et entre la cheville et les métatarsophalangiennes ( $\left.{ }_{C R P}(\mathbf{A}-\mathbf{M})\right)$. On a calculé le coefficient de variance entre la marche avant et la marche arrière inversée pour chaque variable EA et CRP. Le modèle statistique du test T indépendant et du test T apparié, ainsi que l'analyse univariée ont été appliqués avec un niveau de signification de 0,05 et un intervalle de confiance de $95 \%$. Nos résultats montrent que la marche arrière inversée a augmenté significativement l'amplitude des articulations du genou, de la cheville et des métatarsophalangiennes, tandis que la majorité des variables inter-âge CoV-EA ont été moins importantes, à l'exception de CoV-EA (OAB) entre les âges cinq et six. Les variables amplitude-EA ont été enregistrées avec des différences significatives entre la marche avant et la marche arrière inversée dans chaque groupe d'âge. En termes d'effets d'interaction, seulement la direction de marche a montré un impact significatif sur les variables amplitude-EA. Dans l'ensemble, bien que la marche arrière ait augmenté l'amplitude du mouvement dans les articulations du genou, de la cheville et des métatarsophalangiennes, les enfants âgés entre trois et six ans ont déjà développé un mécanisme par lequel le système nerveux central peut contrôler leur marche dans toute direction.

MOTS CLÉS : direction de marche, coordination, phase relative continue, enfants

*Correspondence to: Jin ZHOU, National Engineering Laboratory for Clean Technology of Leather Manufacture, Sichuan University, Chengdu 610065, P.R. China, e-mail: zj_scu@qq.com 


\section{INTRODUCTION}

Human development of motion is a complex process, especially in the age since independent walking to six years old. During this period, not only independent walking is performed, but also 'Neuro-musculo-skeletal' system develops dramatically. After one year of independent walking, their gait pattern transferred from foot flat to heel contact one [1]; while, gait coordination was still developing within period of three to six years old [2]. Since feet are the only parts of the human body contacting with the ground and they play a major role in acceptance of loading during the stance phase and then transfer loading to other parts of the lower limbs. However, activities such as walking, running etc. are under control of 'Neuromusculo-skeletal' system. Thereby, by assessing the performance of children completing various gait tasks, their development in 'Neuro-musculoskeletal' system could be comprehended.

Current research suggested that neural control of forward walking (FW) and backward walking (BW) might largely originate from the same basic neural circuitry [3] and it could be observed from that BW often presented a contrary motion cycle from that of FW. Thereby, gait cycle of BW could be reversed and transferred into reverse backward walking (RevBW) [4] and by comparing with that of FW, degree of children's development in motion could be interpreted. Pieter Meyns [3] contrasted differences of the upper and lower limbs between FW and BW in school-aged children, so as to understand at what age of development they gained the ability of gait control in terms of orientation. In aspect of upper limbs [5], children initially fixed their arms in a high guard position (external rotation in the shoulder, flexed elbows and hands at height of shoulder) and it then gradually changed to a low guard position as age increased (arms extend along the body without active swing). In aspect of lower limbs [6], features of heel strike were considered as a variable assessing the extent of their gait maturation. Phase of heel strike was divided into two stages, one was a very short heel contact, after which knee joint kept the status of

\section{INTRODUCERE}

Dezvoltarea funcției motorii la om este un proces complex, mai ales din momentul în care copilul începe să meargă independent și până la vârsta de șase ani. În această perioadă, pe lângă mersul independent, sistemul neuromuscular se dezvoltă dramatic. După un an de mers independent, tiparul de mers se modifică de la atingerea solului cu toată talpa la contactul cu călcâiul [1], iar coordonarea mersului continuă să se dezvolte în perioada de la trei la șase ani [2]. Întrucât labele picioarelor reprezintă singura parte a corpului uman care intră în contact cu solul, acestea joacă un rol important în susținerea greutății în faza de pășire și apoi transferă această greutate în alte părți ale membrelor inferioare. Cu toate acestea, activități precum mersul, alergarea etc. sunt subordonate sistemului neuromuscular. Prin urmare, evaluarea performanțelor copiilor la îndeplinirea anumitor cerințe legate de mers ajută la înțelegerea dezvoltării sistemului neuromuscular al acestora.

Studiile actuale sugerează că, atât mersul înainte (FW), cât și mersul înapoi (BW) își au originea în același circuit neuronal [3] și se poate observa că mersul înapoi a prezentat deseori un ciclu de mișcare contrar celui specific mersului înainte. Prin urmare, ciclul de mers înapoi a putut fi inversat și transformat în mers înapoi inversat (RevBW) [4] și s-a putut interpreta gradul de dezvoltare a funcției motorie a copiilor în comparație cu mersul înainte. Pieter Meyns [3] a comparat diferențele la nivelul membrelor superioare și inferioare între mersul înainte și mersul înapoi la copiii de vârstă școlară, pentru a înțelege la ce vârstă apare capacitatea de a-și controla mersul în ceea ce privește orientarea. În cazul membrelor superioare [5], copiii își fixează inițial brațele într-o poziție de gardă (rotația exterioară a umerilor, coatele îndoite și mâinile ridicate la nivelul umerilor) apoi se modifică treptat pe măsură ce înaintează în vârstă (brațele întinse de-a lungul corpului fără balans activ). În cazul membrelor inferioare [6], caracteristicile atacului cu călcâiul au fost considerate variabile în evaluarea nivelului de maturitate al mersului copiilor. Etapa atacului cu călcâiul a fost împărțită în două sub-etape: prima reprezentată de un contact foarte scurt al călcâiului, după care articulația genunchiului s-a menținut în extensie, iar cea de a doua reprezentată de contactul 
extension; another was overall contacting of the heel. Whereas, in child population, Hallemans [1] suggested that gait pattern of heel-strike was found in the age of 1.5 years; but other literatures implied that adult-like length, width and frequency of gait were obtained after the age of 13 [7]. Moreover, Fritz [8] explored the correlation between FW and BW in order to interpret the maturation of the gait.

Mathematical model for coordination assessment was recommended to be composed with the factors such as time, angle and velocity at key segments or joints. According to those factors, Miller et al. [9] built a continuous relative phase (CRP) model to quantify the coordination in human walking; besides, they also compared effectiveness and sensitivity of CRP with those of vector coding. Further, by utilizing the CRP model, Chang [10] and Leardini [11] evaluated coordination of rear-foot, mid-foot and fore-foot during the stance phase; while Shiu-Ling Chiu et al. [12] contrasted differences of coordination between young and elder adult in walking with varied velocity. Moreover, distinctions of coordination in various sports [13] or foot deformity groups [14] were also evaluated in current literature. However, there were deviations between FW and RevBW in terms of intra-limb coordination in stance phase of walking of healthy children aged between three and six has not been studied.

Therefore, the aim of this study was first to compare the differences of coordination existed between FW and RevBW in healthy children aged between three and six; and then to explore interaction effects of age and direction of motion on intra-limb coordination. Two hypotheses were proposed: (1) as the age increased, correlation between FW and RevBW promoted gradually; (2) interaction effects of age and direction on coordination were significant.

\section{METHODS}

\section{Subjects}

Totally, 40 healthy children aged between three and six were recruited in this study and four age groups were classified by one-year integral al călcâiului. Hallemans [1] a sugerat că, în rândul copiilor, tiparul de mers care include atacul călcâiului a fost observat la vârsta de un an și jumătate, însă alte studii au arătat că lungimea, lățimea și frecvența mersului se dezvoltă după vârsta de 13 ani [7]. Mai mult decât atât, Fritz [8] a explorat corelația dintre mersul înainte și mersul înapoi pentru a interpreta dezvoltarea mersului.

Se recomandă ca modelul matematic pentru evaluarea coordonării să fie compus din factori precum timpul, unghiul și viteza la articulații sau segmente cheie. Pe baza acestor factori, Miller și colab. [9] au construit un model cu fază continuă relativă (CRP) pentru a cuantifica coordonarea în mersul uman; pe lângă aceasta, autorii au comparat eficiența și sensibilitatea CRP cu cele ale modelelor cu codificare pe bază de vectori. Mai mult, prin utilizarea modelului CRP, Chang [10] și Leardini [11] au evaluat coordonarea retropiciorului, zonei centrale și antepiciorului în timpul fazei de pășire; în timp ce Shiu-Ling Chiu și colab. [12] au comparat diferențele de coordonare dintre adulții tineri și cei mai în vârstă în timpul mersului cu viteze variabile. Mai mult decât atât, în studiile actuale s-au evaluat diferențele de coordonare în cadrul diferitelor sporturi [13] sau în cadrul grupurilor ce prezintă deformări ale picioarelor [14]. Cu toate acestea, nu s-au studiat variațiile dintre mersul înainte și mersul înapoi inversat în ceea ce privește coordonarea membrelor în faza de pășire a mersului la copiii sănătoși cu vârsta între trei și șase ani.

Prin urmare, scopul acestui studiu a fost mai întâi de a compara diferențele de coordonare dintre mersul înainte și mersul înapoi inversat la copiii sănătoși cu vârsta între trei și șase ani și apoi de a explora efectele interacțiunii dintre vârstă și direcția de mișcare asupra coordonării membrelor. S-au propus două ipoteze: (1) pe măsură ce înaintează în vârstă, corelația dintre mersul înainte și mersul înapoi inversat crește treptat; (2) efectele interacțiunii dintre vârstă și direcție asupra coordonării sunt semnificative.

\section{METODE}

\section{Subiecți}

Pentru acest studiu s-au recrutat în total 40 de copii sănătoși cu vârsta între trei și șase ani, clasificându-se în patru grupe de vârstă 
interval. Criterion of inclusion was shown below: (1) without abnormal gait pattern, such as crouch gait; (2) walking independently; (3) without foot deformities or injuries; (4) the range of body weight index (BMI) was consistent with the BMI standard for normal weight of Chinese children [15]. All the measures were carried out after introducing methods and procedures of this study to their parents and receiving their formal approval. All the measurements and procedures followed the principles of Helsinki declaration.

\section{Three-dimensional Motion Captures}

Coda motion system (Coda motion cx1, Charnwood Dynamics Ltd., United Kingdom) was used in this study to obtain the temporalspatial parameters of children's lower limbs while normal walking. Twenty key positions were first marked (Figure 1) and details of those markers were shown below: marker ' $O$ ' was a point of anterior superior iliac spine; marker ' $A 1$ ' and ' $A 2$ ' represented the medial and lateral prominence of the distal of thigh; 'B1' and 'B2' indicated the medial and lateral prominence of ankle; ' $\mathrm{C} 1$ ' and ' $\mathrm{C} 2$ ' are the medial and lateral swell of heel; 'D1' and 'D2' implied the $1^{\text {st }}$ and $5^{\text {th }}$ metatarsophalangeal (MTH); ' $F$ ' was the tip point of the hallux. Based on the mathematical model of virtual points of Odin software (V1.02, Charnwood Dynamics Ltd., United Kingdom), virtual markers of ' $A$ ' (central point of knee), ' $B$ ' (central point of ankle), ' $C$ ' (central point of heel), ' $D$ ' (central point of forefoot) and ' $E$ ' (rear point of heel) were generated. Two collectors were aligned on the two side of the six-meterlong walking track and they were facing with angle of 120 degrees.

All subjects were asked to change their clothes into a tight one when they arrived; and then markers were set by the same researcher. A three to five minute warm-up was provided for their familiarization. Afterwards, subjects walked in their own selected speed on the track and simultaneously the data recording was open; FW and $\mathrm{BW}$ were measured randomly. At least five successful trails would be required for each side of foot. la un interval de un an. Criteriile de includere au fost următoarele: (1) lipsa unui tipar de mers anormal, cum ar fi mersul ghemuit; (2) mers independent; (3) lipsa deformărilor și a leziunilor; (4) intervalul indicelui de masă corporală (IMC) în conformitate cu standardul IMC pentru copiii din China cu greutate normală [15]. Toate măsurătorile au fost efectuate după prezentarea metodelor și procedurilor din acest studiu părinților și primirea aprobării oficiale a acestora. Toate măsurătorile și procedurile au respectat principiile Declarației de la Helsinki.

\section{Captarea mișcării tridimensionale}

În acest studiu s-a utilizat sistemul Coda motion (Coda motion cx1, Charnwood Dynamics Ltd., Marea Britanie) pentru a obține parametrii temporali și spațiali ai membrelor inferioare ale copiilor în timpul mersului normal. S-au marcat mai întâi 20 de poziții-cheie (Figura 1), cu următoarele detalii: markerul ' $O$ ' a reprezentat un punct al coloanei vertebrale iliace antero-superioare; markerii ' $A 1$ ' și 'A2' au reprezentat proeminența interioară și exterioară a segmentului distal al coapsei; 'B1' și 'B2' au indicat proeminența interioară și exterioară $a$ gleznei; 'C1' și 'C2' au reprezentat proeminența interioară și exterioară a călcâiului; 'D1' și 'D2' au indicat primul și al cincilea metatarsian; ' $F$ ' a reprezentat vârful halucelui. Pe baza modelului matematic cu puncte virtuale realizat $\mathrm{cu}$ programul Odin (V1.02, Charnwood Dynamics Ltd., Marea Britanie), s-au generat markerii virtuali ai punctelor ' $A$ ' (punctul central al genunchiului), 'B' (punctul central al gleznei), ' $C$ ' (punctul central al călcâiului), 'D' (punctul central al antepiciorului) și ' $E$ ' (punctul posterior extrem al călcâiului). S-au plasat două unități de colectare, câte una pe fiecare parte a pistei de mers cu lungime de șase metri, poziționate la un unghi de 120 de grade.

Tuturor subiecților li s-a cerut să se schimbe în haine mai strâmte, apoi s-au poziționat markerii de către aceeași persoană. Subiecților li s-au acordat trei-cinci minute pentru familiarizare. După aceea, subiecții au mers cu o viteză la alegere pe pistă, înregistrându-se datele simultan. Mersul înainte și mersul înapoi au fost măsurate aleatoriu. Au fost necesare cel puțin cinci încercări reușite pentru fiecare parte a piciorului. 


\section{Data Processing}

At first, complete stance phases of each side of foot were filtered out; and then they were normalized to $100 \%$ modified gait cycle (MGC); while, time axis of backward walking were reversed and its gait cycle was modified as reversed MGC (RevMGC). Euler angle (EA) ( $\theta$ ) and angular velocity $(\omega)$ in zxy coordination sequence were calculated in the Odin software and flexion/extension and dorsiflexion/ plantarflexion of knee $(\theta(\mathrm{OAB}) / \omega(\mathrm{OAB}))$, ankle $(\theta(\mathrm{ABD}) / \omega(\mathrm{ABD}))$ and $\mathrm{MTH}(\theta$ (BDF) / $\omega$ (BDF)) were chosen for further analysis. Mathematical model of CRP was utilized (EQ 1-4) for coordination analysis between knee-

ankle $\left(\theta_{C R P}(\mathbf{K}-\mathbf{A})\right)$ and ankle-MTH $\left(\theta_{C R P}(\mathbf{A}-\mathbf{M})\right)$. The procedure of calculation was shown below: $\theta$ and $\omega$ were first normalized into $\bar{\theta}$ and $\bar{\omega}$ (EQ 1 and $\mathrm{EQ} 2$ ); and then $\varphi(\mathrm{OAB}), \varphi(\mathrm{ABD})$ and $\varphi$ (BDF) were figured out according to EQ 3; at last, $\theta_{C R P}(\mathbf{K}-\mathbf{A})$ and $\theta_{C R P}(\mathbf{A}-\mathbf{M})$ were resolved (EQ 4). In-phase indicated that $\theta_{C R P}$ was within the range between 0 and 30 degrees; while that of anti-phase was 150 and 180 degrees; further, other angle was classified into out-phase [16].

\section{Statistical Analysis}

Intra-subject's data was first averaged and then inter subjects'. One sample K-S model was used to test normal distribution and all data were approved to be following with the normal distribution; meanwhile distinctions

\section{Prelucrarea datelor}

Mai întâi s-au selectat fazele de pășire complete pentru fiecare parte a piciorului, apoi $\mathrm{s}$-au normalizat la un ciclu de mers modificat $100 \%$ (MGC). Axa timpului pentru mersul înapoi a fost inversată și ciclul de mers a fost modificat, rezultând MGC inversat (RevMGC). Unghiul lui Euler $(\mathrm{EA})(\theta)$ și viteza unghiulară $(\omega)$ în secvența de coordonare zxy au fost calculate cu programul Odin, iar flexiunea/extensia și flexiunea dorsală/flexiunea plantară ale genunchiului ( $\theta(\mathrm{OAB}) / \omega(\mathrm{OAB}))$, gleznei $(\theta(\mathrm{ABD}) / \omega(\mathrm{ABD}))$ și metatarsienelor ( $\theta$ (BDF) $/ \omega$ (BDF)) au fost selectate pentru analiză suplimentară. Modelul matematic CRP a fost utilizat (EC. 1-4) pentru analiza coordonării dintre genunchi și gleznă ( $\left.\theta_{C R P}(\mathbf{K}-\mathbf{A})\right)$ și gleznă-metatarsiene ( $\boldsymbol{\theta}$ (A-M)). Procedura de calcul a fost următoarea: $\theta$ și $\omega$ au fost mai întâi normalizate în $\bar{\theta}$ și $\bar{\omega}$ (Ec. 1 și Ec. 2); apoi $\varphi$ (OAB), $\varphi$ (ABD) și $\varphi$ (BDF) au fost determinate conform Ec. 3; în cele din urmă, $\theta_{C R P}$ (K-A) și $\theta_{C R P}$ (A-M) au fost rezolvate (Ec. 4). Atunci când $\theta_{C R P}$ s-a situat în intervalul dintre 0 și 30 de grade, oscilația a fost în fază, când s-a situat între 150 și 180 de grade, oscilația a fost în antifază, iar când s-a situat în alte unghiuri, oscilația a fost considerată în cuadratură [16].

\section{Analiza statistică}

S-a făcut mai întâi o medie a datelor intra-subiect și apoi a datelor inter-subiect. $\mathrm{S}$-a utilizat modelul K-S cu un eșantion, care a

$$
\begin{gathered}
\bar{\theta}=2\left[\frac{\theta-\min (\theta)}{\max (\theta)-\min (\theta)}\right]-1 \\
\bar{\omega}=\left[\frac{\omega}{\max (\omega)}\right] \\
\varphi(i)=\tan ^{-1}\left[\frac{\bar{\omega}(i)}{\bar{\theta}(i)}\right], \quad i=1,2, \ldots, n \\
\theta_{C R P}(i)=\left|\varphi_{1}(i)-\varphi_{2}(i)\right|
\end{gathered}
$$




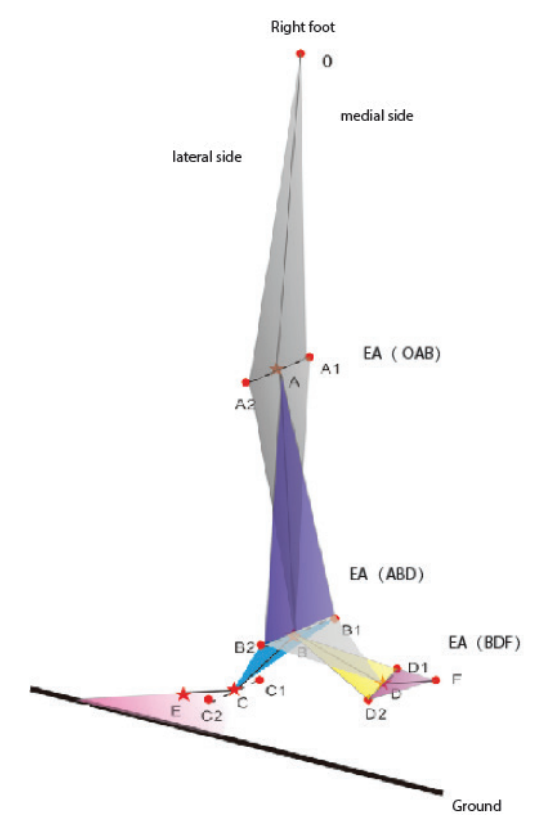

Figure 1. Markers set in the lower limb

Figura 1. Markeri poziţionaţi pe membrul inferior

between left and right foot were examined by independent $T$ test and only right side of lower limbs were considered. Afterwards, according to the $E A$ of $(O A B),(A B D)$ and (BDF) in the $Z$ axis, coefficient of variance ( $\mathrm{CoV}$ ) was calculated in order to assess the correlation between FW and $\mathrm{BW}$, where $\mathrm{CoV}=$ (typical error) / (mean value of FW and RevBW). Inter-age differences of variable of $\mathrm{CoV}$ were evaluated by independent $T$ test; while intra-age differences of amplitude of EA and CRP were assessed by paired-T test. At last, interaction effects of the age (age 3, 4, $5,6)$ and walking direction (FW and RevBW) on the lower limb coordination of healthy children were analyzed by General linear model with repeated measure; where age and walking were considered as the fix factors. All the statistical models were executed under SPSS with significant level of 0.05 and confidence interval of $95 \%$.

\section{RESULTS AND DISCUSSION}

Anthropometrical information of subjects was shown in Table 1.

In terms of inter-age variations, there were significant differences of CoV in $E A(O A B)$ between age of five and six $(p=0.004<0.05)$; while other inter-age deviations were not significant. Moreover, significant intra-age differences also existed in amplitude-EA $(O A B)(p=0.004<0.05$ for age $3 ; p=0.000<0.05$ for age $4 ; p=0.001<0.05$ for confirmat distribuția normală a tuturor datelor. Diferențele dintre piciorul stâng și cel drept au fost examinate cu ajutorul testului $t$ independent și s-a luat în considerare doar partea dreaptă a membrelor inferioare. După aceea, s-a calculat coeficientul de variație (CoV) pe baza punctelor EA al (OAB), (ABD) și (BDF) pe axa Z, pentru a evalua corelația dintre mersul înainte și mersul înapoi, unde CoV = (eroare tipică) / (valoare medie a mersului înainte și mersului înapoi). Diferențele inter-vârstă ale variabilelor CoV au fost evaluate cu ajutorul testului $t$ independent; în timp ce diferențele intra-vârstă ale amplitudinii EA și CRP au fost evaluate cu ajutorul testului $t$ cu eșantioane pereche. În cele din urmă, efectele interacțiunii dintre vârstă $(3,4,5,6$ ani) și direcția de mers (mers înainte și mers înapoi inversat) asupra coordonării membrelor inferioare la copiii sănătoși au fost analizate utilizând modelul liniar general cu măsurători repetate; unde vârsta și mersul sunt considerate factori invariabili. Toate modelele statistice au fost executate cu programul SPSS cu un nivel de semnificație de 0,05 și interval de încredere de 95\%.

\section{REZULTATE ȘI DISCUȚII}

Datele antropometrice ale subiecților sunt prezentate în Tabelul 1.

În ceea ce privește variațiile inter-vârstă, au existat diferențe semnificative ale CoV în punctul $E A(O A B)$ între vârstele cinci și șase ani $(p=0,004<0,05)$; în timp ce alte variații intervârstă nu au fost semnificative. Mai mult decât atât, au existat diferențe semnificative intra- 
Table 1: Anthropometry of the subjects

Tabelul 1: Datele antropometrice ale subiecţilor

\begin{tabular}{ccccc}
\hline $\begin{array}{l}\text { Variables } \\
\text { Variabile }\end{array}$ & Age 3 & Age 4 & Age 5 & Age 6 \\
$\mathrm{~N}$ & $3 \mathrm{ani}$ & 4 ani & 5 ani & 6 ani \\
$\begin{array}{c}\text { Gender }(\mathrm{M} / \mathrm{F}) \\
\text { Sex }(\mathrm{M} / \mathrm{F})\end{array}$ & 10 & 10 & 10 & 10 \\
$\begin{array}{c}\text { Age }(\mathrm{ys}) \\
\text { Vârsta (ani) }\end{array}$ & $1 / 1$ & $1 / 1$ & $1 / 1$ & $1 / 1$ \\
$\begin{array}{c}\text { Weight }(\mathrm{kg}) \\
\text { Greutatea }(\mathrm{kg})\end{array}$ & $14.8 \pm 1.6$ & $4.1 \mathrm{ys} \pm 0.2 \mathrm{ys}$ & & \\
$\begin{array}{c}\text { Height }(\mathrm{cm}) \\
\text { Inălţimea }(\mathrm{cm})\end{array}$ & $96.4 \pm 4.7$ & $17.2 \pm 1.7$ & $5.0 \mathrm{ys} \pm 0.2 \mathrm{ys}$ & $5.9 \mathrm{ys} \pm 0.2 \mathrm{ys}$ \\
$\mathrm{BMI}$ & $105.1 \pm 4.2$ & $17.4 \pm 1.6$ & $19.7 \pm 2.1$ \\
IMC & $15.9 \pm 1.3$ & $15.5 \pm 1$ & $107.2 \pm 1.5$ & $112.5 \pm 5.7$ \\
\hline
\end{tabular}

age $5 ; p=0.020<0.05$ for age 6$)$, amplitude-EA $(A B D)(p=0.000<0.05$ for age $3 ; p=0.000<0.05$ for age $4 ; p=0.005<0.05$ for age $5 p=0.000<0.05$ for age 6) and amplitude-EA (BDF) $(p=0.001<0.05$ for age $3 ; p=0.003<0.05$ for age $4 ; p=0.002<0.05$ for age $5 ; p=0.000<0.05$ for age 6 ) between FW and RevBW, where RevBW was recorded with a higher value than that of FW.

Univariate analysis show that age has no significant effect on the gait coordination; whereas, the walking direction significantly affected the amplitude of EA (OAB) $(p=0.000<0.001), \quad E A \quad(A B D) \quad(p=0.000<0.001)$ and EA (BDF) $(p=0.000<0.001)$; meanwhile, interaction effects from age and walking direction were obtained with less significant impact on the coordination.

\section{Discussion}

In this study, kinematic data while FW and BW of 40 healthy children aged between three and six were first measured; and then their intralimb coordination was calculated. By exploring the variations between FW and RevBW, the effect of walking direction on the motion of healthy children could be interpreted. Our results show that RevBW significantly increased the amplitude of knee, ankle and MTH joint; while majority of inter-age CoV-EA variables were found less prominent, with exception of CoV-EA (OAB) between ages of five to six. Amplitude-EA variables were recorded with significant differences between FW and RevBW in each age group. In terms of interaction effects, only walking direction showed significant impact vârstă la amplitudine-EA (OAB) $(p=0,004<0,05$ pentru vârsta de 3 ani; $p=0,000<0,05$ pentru vârsta de 4 ani; $p=0,001<0,05$ pentru vârsta de 5 ani; $p=0,020<0,05$ pentru vârsta de 6 ani), amplitudine-EA (ABD) $\quad(p=0,000<0,05$ pentru vârsta de 3 ani; $p=0,000<0,05$ pentru vârsta de 4 ani; $p=0,005<0,05$ pentru vârsta de 5 ani; $p=0,000<0,05$ pentru vârsta de 6 ani) și amplitudine-EA (BDF) $\quad(p=0,001<0,05$ pentru vârsta de 3 ani; $p=0,003<0,05$ pentru vârsta de 4 ani; $p=0,002<0,05$ pentru vârsta de 5 ani; $p=0,000<0,05$ pentru vârsta de 6 ani) între mersul înainte și mersul înapoi inversat, unde pentru mersul înapoi inversat s-a înregistrat o valoare mai mare decât cea pentru mersul înainte.

Analiza univariată indică faptul că vârsta nu are niciun efect semnificativ asupra coordonării mersului; în timp ce direcția de mers a afectat semnificativ amplitudinea EA (OAB) $(p=0,000<0,001)$, EA (ABD) $(p=0,000<0,001)$ și EA (BDF) $(p=0,000<0,001)$. Efectele interacțiunii vârstei și direcției de mers au avut un impact mai puțin semnificativ asupra coordonării.

\section{Discuții}

În acest studiu, s-au măsurat mai întâi datele cinematice în timpul mersului înainte și înapoi la 40 de copii sănătoși cu vârsta între trei și șase ani, apoi s-a calculat coordonarea membrelor acestora. Prin explorarea variațiilor dintre mersul înainte și mersul înapoi inversat, $\mathrm{s}$-a putut interpreta efectul direcției de mers asupra mișcării copiilor sănătoși. Rezultatele noastre arată că mersul înapoi inversat a crescut semnificativ amplitudinea articulațiilor genunchilor, gleznelor și metatarsienelor, iar majoritatea variabilelor CoV-EA inter-vârstă au fost mai puțin semnificative, cu excepția 


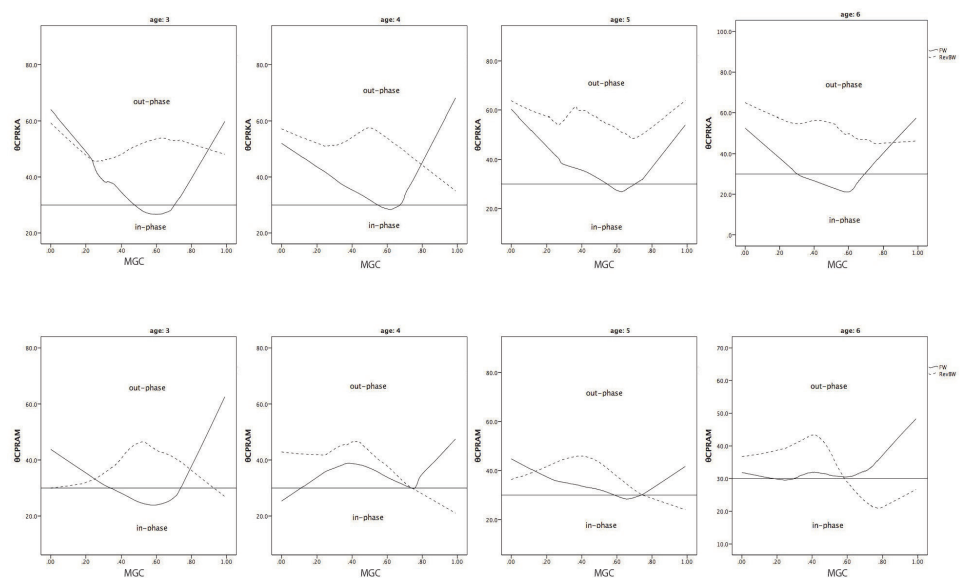

Figure 2. Tracks of continuous relative phase of FW and RevBW

Figura 2. Diagramele fazelor continue relative în mersul înainte și mersul înapoi inversat

on the variables of amplitude-EA.

Results of Myens [3] suggested that most of the gait mechanism in normal walking were limited in that of RevBW; meanwhile, they reported reduced gait coordination stability when walking backwards. However, other researchers showed that differences between FW and RevBW were small, which could also be confirmed by outcomes of CoV in our study. Similar with the vision being artificially blinded [17], walking speed of RevBW was lowered, as the information after back was unknown. Reduced walking speed could cause a larger range of joint motion. It was the reason that all variables of amplitude in knee, ankle and MTH joints were obtained with significant higher value than that of FW. Jansen [18] implied that since the heel contact in RevBW, the main cushion occurred in the forefoot; thereby a more muscle of anterior tibia actions were required.

Myens [3] further indicated that age exhibited mild effects on a few specific kinematic gait characteristics measured in a group of primary school-aged children, such as amplitude of lower leg, foot elevation angles, timing of the first peak or valley of the upper leg and lower leg elevation angles. In the viewpoint of Sutherland [6], gait features such as step length, width and frequency were full-filled between age of four and seven. Our finding confirmed that develop of children's gait control in RevBW was earlier than the existing research. In contrast between FW and RewBW, only variable of CoV-EA (OAB) was recorded with significant differences between age of five and six. Moreover, interaction effects
CoV-EA (OAB) între vârstele de cinci și șase ani. S-au înregistrat variabilele amplitudine-EA cu diferențe semnificative între mersul înainte și mersul înapoi inversat în fiecare grupă de vârstă. În ceea ce privește efectele de interacțiune, doar direcția de mers a prezentat un impact semnificativ asupra variabilelor amplitudine-EA.

Rezultatele lui Myens și colab. [3] au sugerat că, în mare parte, mecanismul de mers a fost limitat în mersul înapoi inversat; totodată, aceștia au raportat o stabilitate redusă a coordonării în timpul mersului înapoi. $\mathrm{Cu}$ toate acestea, alți cercetători au arătat că diferențele dintre mersul înainte și mersul înapoi inversat au fost mici, ceea ce poate fi confirmat și de rezultatele CoV din studiul nostru. În mod asemănător cu orbirea artificială [17], viteza de mers în mersul înapoi inversat a scăzut, întrucât nu au existat informații. Viteza redusă de mers a dus la o mișcare a articulației mai amplă. Acesta a fost motivul pentru care toate variabilele amplitudinii la articulațiile genunchilor, gleznelor și metatarsienelor au avut o valoare semnificativ mai mare decât cea obținută în cazul mersului înainte. Jansen [18] a sugerat că, întrucât în mersul înapoi inversat contactul se face cu călcâiul, antepiciorul devine principala zonă de amortizare; prin urmare, este necesar un efort muscular mai mare pentru antrenarea marginii anterioare a tibiei.

Myens [3] a mers mai departe indicând că, într-o măsură mică, vârsta influențează câteva caracteristici cinematice ale mersului măsurate la un grup de copii de vârstă școlară, precum amplitudinea părții inferioare a piciorului, unghiurile de elevație ale labei piciorului, momentul primului punct maxim sau punctul minim al unghiurilor de elevație ale părților superioară și inferioară ale piciorului. Din 


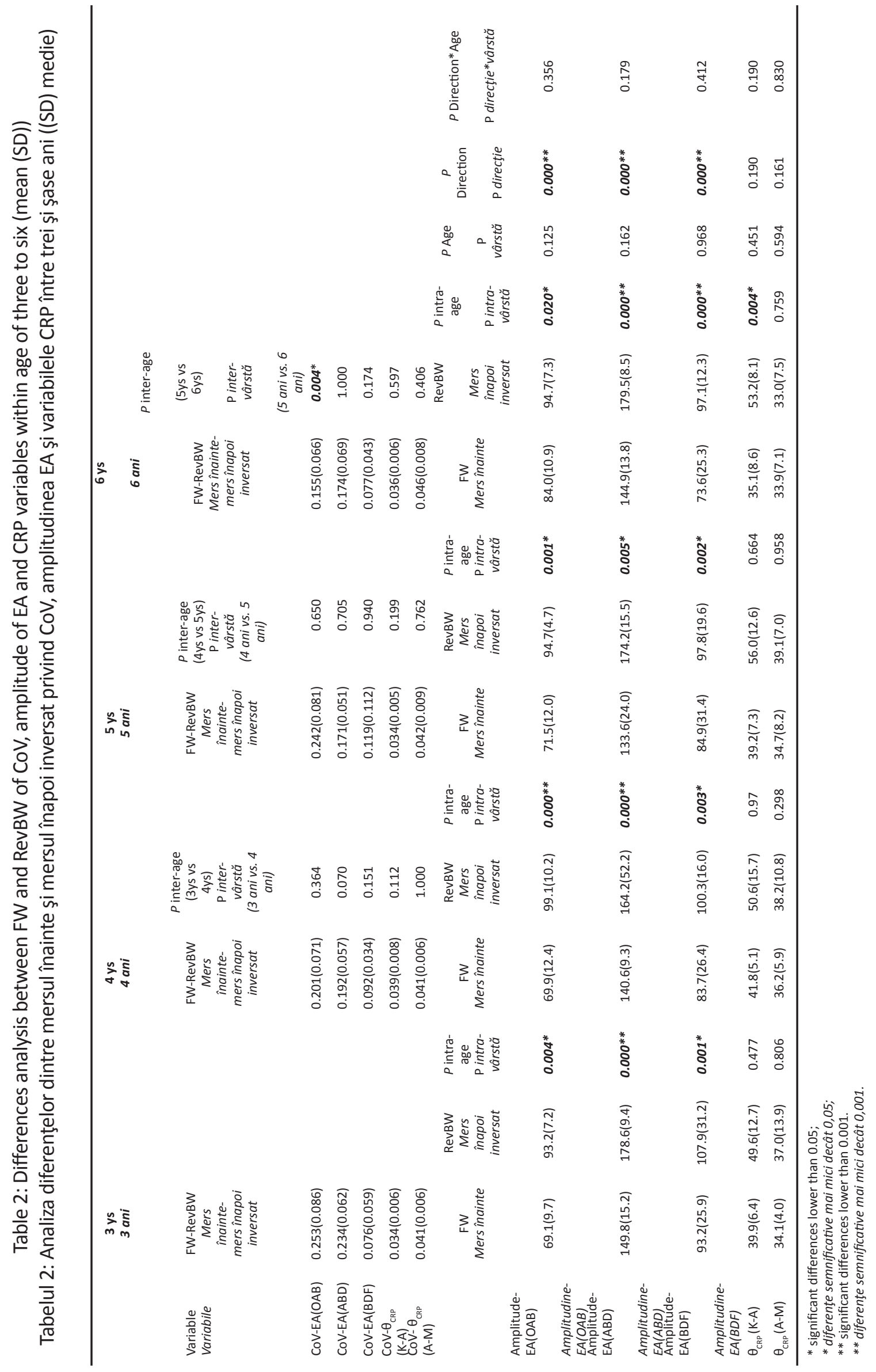


of age and walking direction were showed no significant impact on the coordination variables. Hence, we implied that children aged between three and six have mastered the gait control when walking backwards. Our finding could be explained by Dietz [19], who reported that in humans basic neural control could be simply transferred between the mode of walking forwards and backwards.

\section{CONCLUSION}

Overall, although BW increased amplitude of motion in knee, ankle and MTH joint, children aged between three and six have already achieved a mechanism that central nervous system could switch their gait control freely. perspectiva lui Sutherland [6], caracteristici ale mersului precum lungimea, lățimea și frecvența pașilor se dezvoltă complet între vârstele de patru și șapte ani. Rezultatele noastre au confirmat că dezvoltarea controlului asupra mersului în mersul înapoi inversat a avut loc mai devreme decât în alte studii existente. Comparând mersul înainte și mersul înapoi inversat, doar variabila CoV-EA (OAB) a prezentat diferențe semnificative între vârstele cinci și șase. Mai mult decât atât, efectele interacțiunii dintre vârstă și direcția de mers nu au prezentat un impact semnificativ asupra variabilelor de coordonare. Prin urmare, am dedus că copiii cu vârste între trei și șase ani au dobândit control în mersul înapoi. Rezultatul nostru poate fi explicat de Dietz [19], care a raportat că, la oameni, controlul neuronal de bază poate fi pur și simplu transferat între modurile de mers înainte și înapoi.

\section{CONCLUZII}

Per ansamblu, deși în situația mersului înapoi a crescut amplitudinea mișcării în zona articulațiilor genunchilor, gleznelor și metatarsienelor, copiii cu vârste între trei și șase ani au dezvoltat un mecanism care permite sistemului nervos central să-și controleze mersul în orice direcție.

\section{REFERENCES}

1. Hallemans, A., D’Août, K., De Clercq, D., Aerts, P., Foot and Ankle International, 2003, 24, 444-453.

2. Bosch, K., Gerss, J., Rosenbaum, D., Gait Posture, 2010, 32, 564-71.

3. Meyns, P., Desloovere, K., Molenaers, G., Swinnen, S.P., Duysens, J., PLOS ONE, 2013, 8, e62747-e62747.

4. Duysens, J., Tax, A.A., Murrer, L., Dietz, V., J Neurophysiol, 1996, 76, 301-310.

5. Ledebt, A., Infant Behav Dev, 2000, 23, 79-89.

6. Sutherland, D.H., Olshen, R., Cooper, L., Woo, S.L., J Bone Joint Surg Am, 1980, 62, 3, 336-353.

7. Lythgo, N., Wilson, C., Galea, M., Gait Posture, 2009, 30, 502-506.

8. Fritz, N.E., Worstell, A.M., Kloos, A.D., Siles, A.B., White, S.E., Kegelmeyer, D.A., Gait Posture, 2013, 37, 4, 593-597.

9. Miller, R.H., Chang, R., Baird, J.L., Van Emmerik, R.E.A., Hamill, J., J Biomech, 2010, 43, 13, 2554-2560.

10. Chang, R., Van Emmerik, R., Hamill, J., J Biomech, 2008, 41, 3101-3105.

11. Leardini, A., Benedetti, M.G., Berti, L., Bettinelli, D., Nativo, R., Giannini, S., Gait Posture, 2007, 25, 3, 453-462.

12. Chiu, S.L., Chou, L.S., J Biomech, 2012, 45, 275-280.

13. Krasovsky, T., Lamontagne, A., Feldman, A.G., Levin, M.F., Gait Posture, 2014, 39, 378-385.

14. Wilson, C., Simpson, S.E., Van Emmerik, R.E.A., Hamill, J., Sports Biomech, 2008, 7, 1, 2-9.

15. Chinese Obesity Working Group, Chinese Journal of Epidemiology, 2004, 25, 2, 97-102.

16. Rose, J., Wolff, D.R., Jones, V.K., Bloch, D.A., Oehlert, J.W., Gamble, J.G., Dev Med Child Neurol, 2002, 44, 1, 58-63.

17. Eva, D.H. et al., Gait Posture, 2011, 33, 42-42.

18. Jansen, K., De Groote, F., Massaad, F., Meyns, P., Duysens, J., Jonkers, I., J Neurophysiol, 2012, 107, 3385-3396.

19. Dietz, V., Trends Neurosci, 2002, 25, 9, 462-467.

Article received/Data primirii articolului: 08.07.2016

Accepted/Acceptat la data: 12.09.2016 